\title{
Awareness of households to the benefits of Achuete (Bixa Orellana) in Central Luzon
}

\author{
Geena Baltazar Hipolito, Ph.D
}

Department Chair, Department of Agricultural Business and Economics and Entrepreneurship, Focal Person, Gender and Development, Assistant Director, Office of the Business Affairs, Pampanga State Agricultural University, Philippines

\begin{abstract}
As a tropical country(Philippines), it is important to find natural resources, such as plants, which could have different impact to the community and the government. This paper determined the level of awareness of households on the utilization and socio-economic benefits of achuete. Also, this paper described the economic impact and social benefits on the commercialization of achuete. This paper used descriptive method. A total of 120 households were surveyed using a questionnaire with likert-scale responses. Based on the data gathered, household respondents were mostly high school graduates having a small household size and living for more than 21 years in their locality. Farmer respondents were moderately aware on the uses of Atsuete plant, its economic benefits, and its social impact. On the other hand, respondents were somewhat aware on its socioeconomic and health benefits. Their awareness on the uses of annatto plants focus on its benefits for food preparation, can be used as synthetic colorant, and could be a potential source of income. Likewie, the know that planting and producing Atsuete plants may give benefits for the income of the family. Therefore, recommendations for regarding the results of the study are as follows: (1) agencies related to production of Atsuete should provide programs to increase awareness of rural households on the socio-economic and health benefits of Atsuete; (2) appropriate technology must be identified to enhance the production of Atsuete plants; (3) there must be policy recommendation on the production and utilization of Atsuete; and (4) there should also be a focus on the market enhancement of Atsuete plants to help households to have an economic benefit for them.
\end{abstract}

Keywords-Bixa Orellana, Achuete, Awareness, Benefits.

\section{INTRODUCTION}

As a tropical country(Philippines), it is important to find natural resources, such as plants, which could have different impact to the community and the government. Urban sustainability has been linked to the preservation of balanced and cohesive retail systems established in a wide variety of facilities, shopping environments and locations (Cachinho, 2014). Bixa orellana seeds, commonly called achuete, are used in the Philippines for food colouring (Raga et al., 2011).

Achuete is used as an astringent and mild purgative and is regarded as a good remedy for dysentery and kidney disease treatment (De Vera et al., 2016). When taken internally or orally, the plant offers itself as an antidote for prussic acid, antimicrobial, purgative, and antidiarrheal effect (Valdez \& Canapi, 2015). The leaf infusion has been shown to be effective against bronchitis, sore throat and inflammation of the eyes (Villar et al., 2014). The leaf extracts of Achuete had antihistaminic activity, as evidenced by the suppression of increased vascular permeability (Yong et al., 2013). Improving the Achuete color content on standing crops is a necessity of the day as they are perennial in nature and will pay a significant amount of return (Giridhar \& Parimalan, 2010).

With the further insights, the researcher assessed the awareness of the households in the Philippines about the traditional and medicinal uses of Achuete which could have an economic impact to the government and socio-economic benefit to the community.

\section{CONCEPTUAL FRAMEWORK}

For its medical, nutraceutical and nutritional potential values it is important to promote the intake of achuete seeds and 
pigment in the diet, as well as to promote its cultivation and production (Rivera-Madrid et al., 2016).

Natural colors from plant sources for edible purposes are of great importance from the point of view of health, and also from the acceptance and preference of consumers (Venugopalan, 2011).

Achuete as an export crop and foreign exchange earner should be supported by the government in terms of introducing favorable input tax incentives, developing trade policies to protect small-scale farmers (Cheruiyot et al., 2019).

\section{OBJECTIVES OF THE STUDY}

This paper determined the level of awareness of households on the utilization and socio-economic benefits of achuete. Also, this paper described the economic impact and social benefits on the commercialization of achuete.

\section{METHODOLOGY}

The descriptive method of research was used in this study because it involves description, recording, analysis and interpretation of condition that really exists. It is appropriate to use descriptive method in gathering information about the present existing condition (Creswell, 2014). A total of 120 households were surveyed using a questionnaire with likertscale responses (Vagias, 2006).

Primary and secondary data were utilized in this study. Primary data were gathered from the survey conducted with the DA-AMAD Central Luzon research team with the assistance of Provincial and Municipal Agriculture Officers for the production, utilization and trade of Annato. Pampanga, Nueva Ecija, Tarlac and Bataan covered the data of the study.

\section{RESULTS AND DISCUSSIONS}

Table 1. Socio-Demographic Profile of the respondents

\begin{tabular}{|c|c|c|c|}
\hline Demographic Characteristics & & Frequency (n) & Percentage $(\%)$ \\
\hline \multicolumn{4}{|l|}{ Sex } \\
\hline Male & & 33 & 27.5 \\
\hline Female & & 87 & 73.5 \\
\hline & Total & 120 & 100 \\
\hline \multicolumn{4}{|l|}{ Age } \\
\hline $21-30$ & & 13 & 10.8 \\
\hline $31-40$ & & 37 & 30.8 \\
\hline $41-50$ & & 41 & 34.2 \\
\hline $51-60$ & & 26 & 21.7 \\
\hline 61-above & & 3 & 2.5 \\
\hline & Total & 120 & 100 \\
\hline \multicolumn{4}{|l|}{ Civil Status } \\
\hline Single & & 5 & 4.2 \\
\hline Married & & 111 & 92.5 \\
\hline Widowed & & 4 & 3.3 \\
\hline & Total & 120 & 100 \\
\hline \multicolumn{4}{|l|}{ Educational Attainment } \\
\hline High School Undergraduate & & 7 & 5.8 \\
\hline High School Graduate & & 79 & 65.8 \\
\hline
\end{tabular}




\section{Vocational \\ College Undergraduate \\ College Graduate}

$\begin{array}{ccc} & 4 & 3.3 \\ & 17 & 14.2 \\ & 13 & 10.8 \\ \text { Total } & \mathbf{1 2 0} & \mathbf{1 0 0}\end{array}$

\section{Household Size}

$$
3-5
$$$$
5-6
$$

7-9

$\begin{array}{ccc} & 83 & 69.2 \\ & 25 & 20.8 \\ & 12 & 10.0 \\ \text { Total } & \mathbf{1 2 0} & \mathbf{1 0 0}\end{array}$

\section{Length of Residency in the Locality}

$$
\text { 16-20 }
$$

21-25

26-30

$31-35$

$36-40$

\section{1}

56

22

7

4
25.8

46.7

18.3

5.8

3.3

$\begin{array}{lll}\text { Total } & 120 & 100\end{array}$

Table 1 shows the demographic characteristics of the 120 respondents which majority of them were females $(73.5 \%)$. Most of the respondents were in the age range of $41-50$ years old $(34.2 \%)$ and majority were married $(92.5 \%)$. A big number of respondents were high school graduate (65.8\%). Majority of the respondents' household size were composed of 3-5 members (69.2\%) and have already resided in their locality for range of $21-25$ years $(46.7 \%)$

\begin{tabular}{|c|c|c|c|}
\hline I am aware that ... & $\begin{array}{c}\text { Mean } \\
\text { (M) }\end{array}$ & $\begin{array}{c}\text { Verbal } \\
\text { Description }\end{array}$ & Level of Awareness \\
\hline $\begin{array}{l}\text { 1. the seeds of annatto are used for } \\
\text { coloring food }\end{array}$ & 4.21 & Strongly Agree & Fully aware \\
\hline $\begin{array}{l}\text { 2. the different parts of the annatto plant } \\
\text { are used to heal small burns and other } \\
\text { various types of illnesses }\end{array}$ & 1.82 & Disagree & Somewhat aware \\
\hline $\begin{array}{l}\text { 3. annatto seeds are used as antidote for } \\
\text { cassava and } J \text {. curcas poisoning }\end{array}$ & 1.56 & Strongly Disagree & Slightly aware \\
\hline $\begin{array}{l}\text { 4. the organic dye (annatto) is used to } \\
\text { provide an attractive color to meat and } \\
\text { other dishes }\end{array}$ & 3.28 & Strongly Agree & Fully aware \\
\hline $\begin{array}{l}\text { 5. the dye is used in cosmetic industry as } \\
\text { an organic colorant and also in the many } \\
\text { of the household products }\end{array}$ & 2.45 & Disagree & Somewhat aware \\
\hline
\end{tabular}

Table 2. Awareness of respondents on the uses of Atsuete (annatto plant) 
6. the wood/fibers of the plant are used to make ropes and twines

General Weighted Mean

Legend

$\begin{array}{ll}3.25-4.00 & \text { Fully Aware } \\ 2.50-3.24 & \text { Moderately Aware }\end{array}$

2.50 - $3.24 \quad$ Moderately Aware

Table 2 shows the level of awareness of respondents on the uses of Atsuete plants. Based on the result, respondents were moderately aware on the uses of Atsuete plants with a general weighted mean of 2.53 . To hightlight, respondents were fully aware of its two uses: the seeds of annatto are used for coloring food $(M=4.21)$ and the organic dye (annatto) is used to provide an attractive color to meat and other dishes $(\mathrm{M}=$
1.88

Disagree

Somewhat aware

2.53

Agree

Moderately aware

1.75-2.49 Somewhat Aware

$1.00-1.74 \quad$ Slightly Aware

Table 3. Awareness of the respondents on the socio-economic benefits of atsuete

\begin{tabular}{|c|c|c|c|}
\hline I am aware that atsuete ... & $\begin{array}{c}\text { Mean } \\
\text { (M) }\end{array}$ & $\begin{array}{c}\text { Verbal } \\
\text { interpretation }\end{array}$ & Level of Awareness \\
\hline $\begin{array}{l}\text { 1. could give additional source of nutrients for } \\
\text { the family or community }\end{array}$ & 1.54 & Strongly Disagree & Slightly Aware \\
\hline $\begin{array}{l}\text { 2. reduces health risk from the utilization of } \\
\text { synthetic colorants }\end{array}$ & 3.28 & Strongly Agree & Fully Aware \\
\hline $\begin{array}{l}\text { 3. can give additional source of income for the } \\
\text { family/community }\end{array}$ & 3.52 & Strongly Agree & Fully Aware \\
\hline $\begin{array}{l}\text { 4. could give opportunity to create new recipes } \\
\text { and products }\end{array}$ & 3.75 & Strongly Agree & Fully Aware \\
\hline $\begin{array}{l}\text { 5. can be a source of healing/treating agents } \\
\text { for various types of illnesses }\end{array}$ & 1.88 & Disagree & Somewhat Aware \\
\hline $\begin{array}{l}\text { 6. could provide aesthetic for the family and } \\
\text { other people }\end{array}$ & 2.46 & Disagree & Somewhat Aware \\
\hline $\begin{array}{l}\text { 7. could Increase soil productivity from the } \\
\text { litters given by the plant }\end{array}$ & 1.48 & Strongly Disagree & Slightly Aware \\
\hline $\begin{array}{l}\text { 8. could give additional knowledge and } \\
\text { opportunity on agriculture }\end{array}$ & 2.74 & Agree & Moderately Aware \\
\hline $\begin{array}{l}\text { 9. can open additional livelihood opportunities } \\
\text { in marketing and processing sector }\end{array}$ & 2.32 & Disagree & Somewhat Aware \\
\hline $\begin{array}{l}\text { 10. can enhance environmental and economic } \\
\text { condition through silviculture }\end{array}$ & 1.81 & Disagree & Somewhat Aware \\
\hline General Weighted Mean & 2.52 & Agree & Somewhat Aware \\
\hline Fully Aware & $1.75-2.49$ & Somewhat Aware & \\
\hline Moderately Aware & $1.00-1.74$ & Slightly Aware & \\
\hline
\end{tabular}

3.28). The results imply that respondents knows that annatto can be used in preparing of food. On the other hand, results showed that respondents were slightly aware that Atsuete (annatto) seeds are used as antidote for cassava and J. curcas poisoning. This implies that respondent have little knowledge on the use of atsuete seed in terms of medicinal uses. 
Table 3 presents the level of awareness of the respondents on the socio-economic benefits of Atsuete. Results showed that respondents are somewhat aware on the socio-economic benefits of Atsuete having a general weighted mean of 2.52 . They strongly agreed that the socio-economic benefits of Atsuete were: it could give opportunity to create new recipes and products $(\mathrm{M}=3.75)$, can give additional source of income for the family/community $(\mathrm{M}=3.52)$, and reduces health risk from the utilization of synthetic colorants $(M=3.28)$. These results suggest that the socio economic benefits of Atsuete were mainly for food and source of colorants. On the other hand, respondents were slightly aware on the benefit of Atsuete that it could increase soil productivity from the litters given by the plant $(\mathrm{M}=1.48)$.

Table 4. Awareness of the respondents on the economic benefits of Atsuete

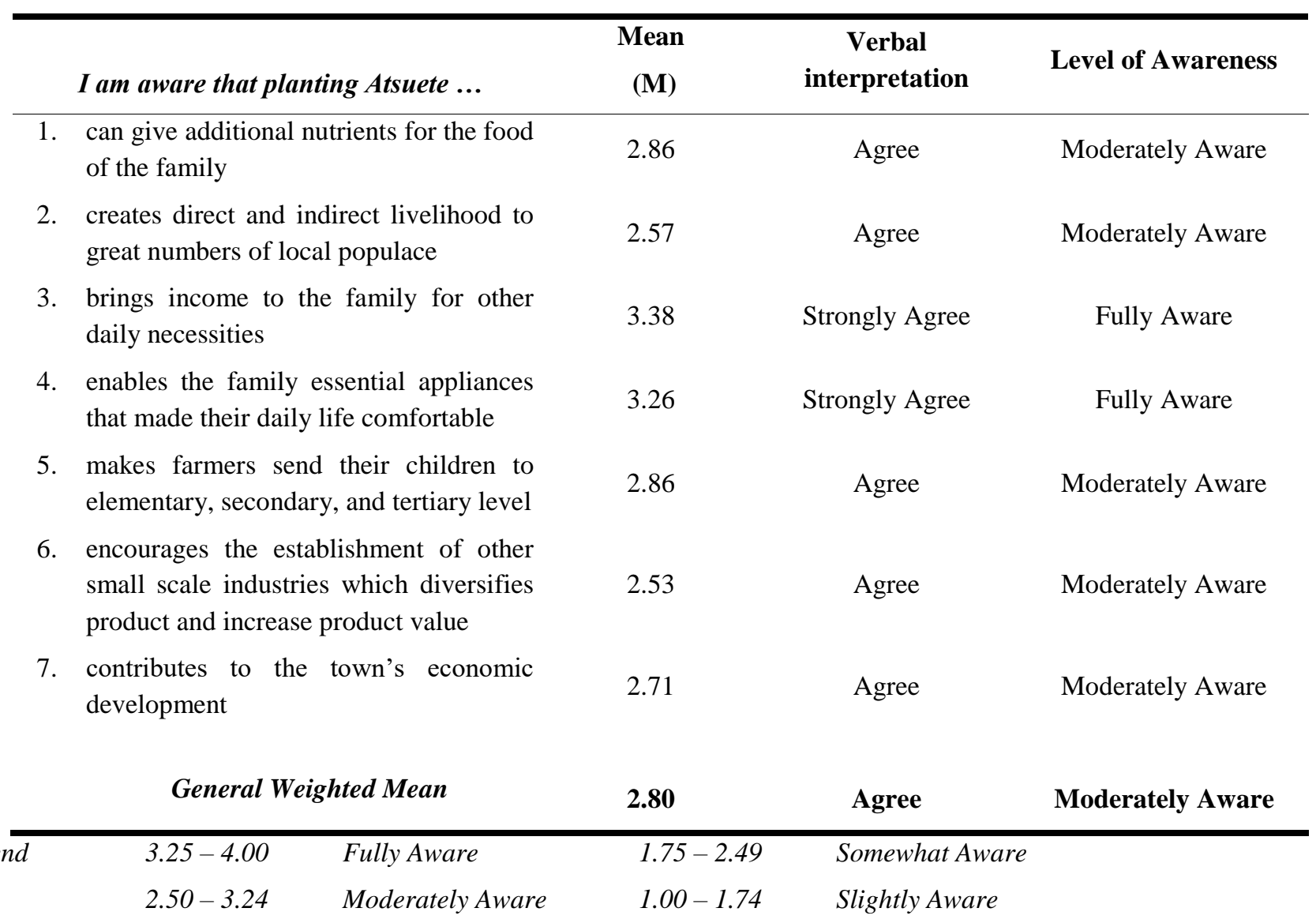

Table 4 shows the level of awareness of the respondents on the economic benefits of Atsuete. Based on the results, the respondents were moderately aware of the economic benefits of Atsuete having a general weighted mean of 2.80. To highlight, the respondents were fully aware on some of its benefits like planting Atsuete brings income to the family for other daily necessities $(M=3.28)$ and enables the family essential appliances that made their daily life comfortable (M =3.26). This implies that the knowledge of the respondents on the economic benefits of Atsuete is how could it help on the needs of their family. 
Table 5. Awareness of the respondents on the Social benefits of atsuete

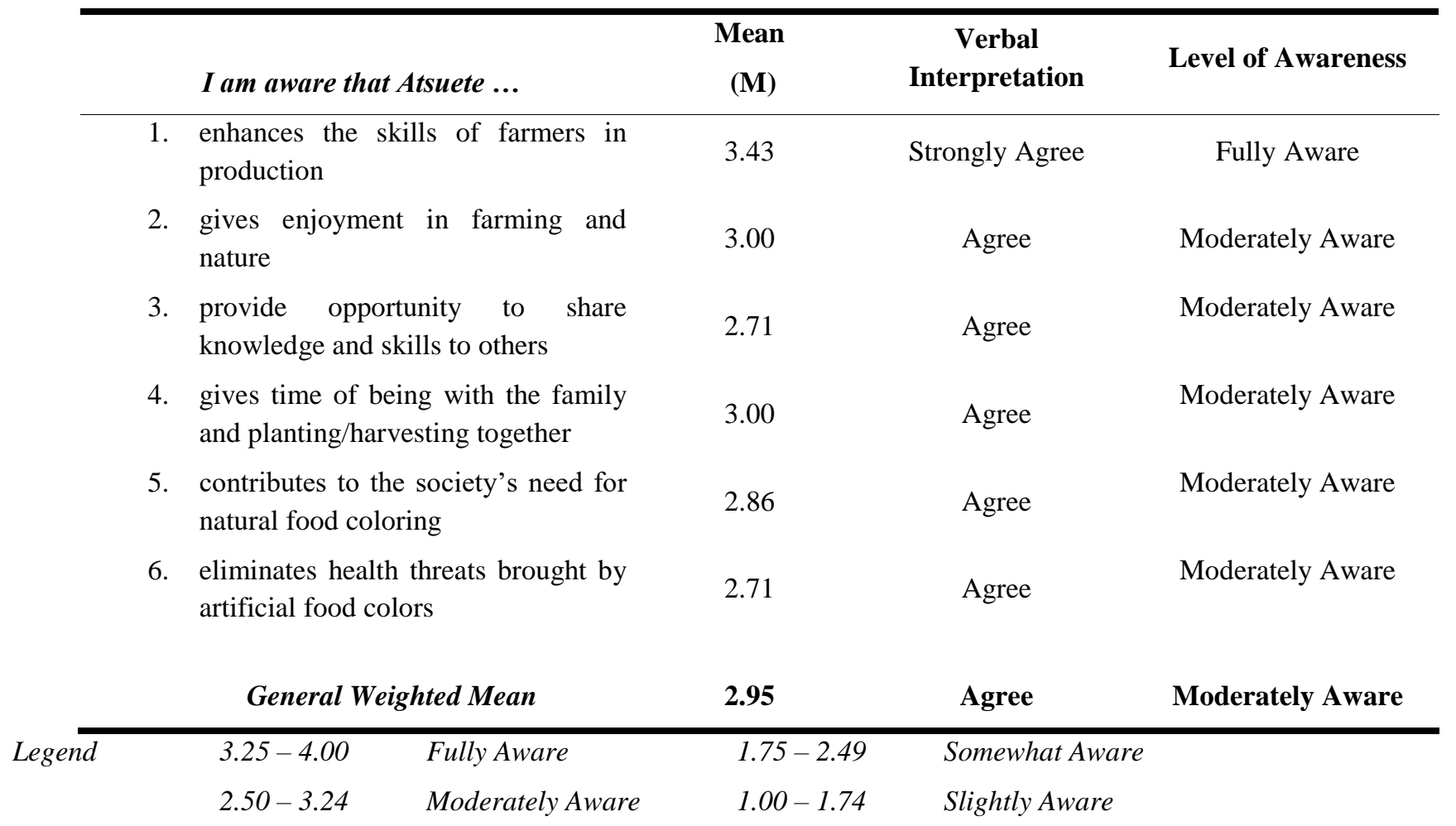

Table 5 shows that respondents were moderately aware on the social benefits of Atsuete having a general weighted mean of 2.95. They strongly agree that Atsuete enhances the skills of farmers in production (3.43). This results suggest that planting Atsuete can give opportunity to develop other skill in farming especially production. Further, results also show that respondents were moderately aware that planting atsuete gives enjoyment in farming and nature $(\mathrm{M}=3.00)$ and gives time of being with the family and planting/harvesting together $(\mathrm{M}=$ 3.00).

\section{CONCLUSIONS AND RECOMMENDATIONS}

Based on the data gathered, household respondents were mostly high school graduates having a small household size and living for more than 21 years in their locality. Farmer respondents were moderately aware on the uses of Atsuete plant, its economic benefits, and its social impact. On the other hand, respondents were somewhat aware on its socio-economic and health benefits. Their awareness on the uses of annatto plants focus on its benefits for food preparation, can be used as synthetic colorant, and could be a potential source of income. Likewie, the know that planting and producing Atsuete plants may give benefits for the income of the family.

Therefore, recommendations for regarding the results of the study are as follows: (1) agencies related to production of Atsuete should provide programs to increase awareness of rural households on the socio-economic and health benefits of Atsuete; (2) appropriate technology must be identified to enhance the production of Atsuete plants; (3) there must be policy recommendation on the production and utilization of Atsuete; and (4) there should also be a focus on the market enhancement of Atsuete plants to help households to have an economic benefit for them.

\section{REFERENCES}

[1] Cachinho, H. (2014). Consumerscapes and the resilience assessment of urban retail systems. Cities, 36, 131-144.

[2] Cheruiyot, D. K., Mwaura, P., \& Tanui, J. K. The moderating influence of Bixa orellana value chain government policy on the relationship between promotion strategy and sales performance.

[3] Creswell, J. W. (2014). A concise introduction to mixed methods research. SAGE publications. 
[4] De Vera, J. S., De Castro, M. E. G., \& Dulay, R. M. R. (2016). Phytochemical Constituents and Teratogenic Effect of Lyophilized Extracts of Bixa orellana L.(Achuete) and Piper betle L.(Ikmo) Leaves in Danio rerio Embryos.

[5] Giridhar, P., \& Parimalan, R. (2010). A biotechnological perspective towards improvement of annatto color production for value addition-the influence of biotic elicitors. Asian Pacific Journal of Molecular Biology and Biotechnology, 18(1), 77-79.

[6] Raga, D. D., Espiritu, R. A., Shen, C. C., \& Ragasa, C. Y. (2011). A bioactive sesquiterpene from Bixa orellana. Journal of natural medicines, 65(1), 206-211.

[7] Rivera-Madrid, R., Aguilar-Espinosa, M., Cárdenas-Conejo, Y., \& Garza-Caligaris, L. E. (2016). Carotenoid derivates in achiote (Bixa orellana) seeds: synthesis and health promoting properties. Frontiers in plant science, 7, 1406.

[8] Vagias, Wade M. (2006). "Likert-type scale response anchors. Clemson International Institute for Tourism \& Research Development, Department of Parks, Recreation and Tourism Management. Clemson University

[9] Venugopalan, A., Giridhar, P., \& Ravishankar, G. A. (2011). Food, ethanobotanical and diversified applications of Bixa orellana L.: a scope for its improvement through biotechnological mediation. Indian Journal of Fundamental and Applied Life Sciences, 1(4), 2231-63459.

[10] Vilar, D. D. A., Vilar, M. S. D. A., Raffin, F. N., Oliveira, M. R. D., Franco, C. F. D. O., de Athayde-Filho, P. F., ... \& Barbosa-Filho, J. M. (2014). Traditional uses, chemical constituents, and biological activities of Bixa orellana L.: a review. The Scientific World Journal, 2014.

[11] Yong, Y. K., Zakaria, Z. A., Kadir, A. A., Somchit, M. N., Lian, G. E. C., \& Ahmad, Z. (2013). Chemical constituents and antihistamine activity of Bixa orellana leaf extract. BMC Complementary and Alternative Medicine, 13(1), 1-7. 